\title{
EVALUATION OF SIESMIC RESPONSE OF SYMMETRIC AND ASYMMETRIC MULTISTOREYED BUILDINGS
}

\author{
T. Seshadri Sekhar ${ }^{1}$, Md. Jaweed Jilani Khan ${ }^{2}$ \\ ${ }^{I}$ Department of Civil Engineering, Gitam University, Hyderabad Campus, India \\ ${ }^{2}$ Structural Engineering PHD Student, Gitam University, Hyderabad Campus, India
}

\begin{abstract}
A building on hill slope differs in different way from other buildings. The various floors of such buildings steps back towards the hill slope and at the same time building may have setbacks also. Due to varied configurations of buildings in hill areas, these buildings become highly irregular and asymmetric. Buildings constructed in hill areas are much more vulnerable to seismic environment. In this study, 3D analytical model of four and nine storied buildings have been generated for symmetric and asymmetric building models and analyzed using structural analysis tool "ETABS Nonlinear". To study the effect of varying height of columns in ground storey due to sloping ground, the plan layout is kept similar for both buildings on plane and sloping ground. The analytical model of the building includes all important components that influence the mass, strength, stiffness and deformability of the structure. To study the effect of infill during earthquake, seismic analysis using both linear dynamics (response spectrum method) as well as nonlinear static procedure (pushover) has been performed.
\end{abstract}

Keywords: Symmetrical and Asymmetrical, Response spectrum method, Push over Method, Displacement, Drifts. $* * *$

\section{INTRODUCTION}

Multistoried R.C. framed buildings are getting popular in hilly areas because of increase in land cost and under unavoidable circumstances due to shortage of land in urban areas. Thus, many of them are constructed on hilly slopes. Setback multistoried buildings are frequent over level grounds whereas stepback buildings are quite common on hilly slopes. Buildings in hilly areas are irregular and asymmetric and therefore are subjected to severe torsion in addition to lateral forces under the action of earthquake forces. Many buildings on hill slopes are supported by columns of different heights. The shorter columns attract more forces as the stiffness of the short columns is more and undergo damage when subjected to earthquakes.

This study seeks to understand the Nonlinear static (pushover) analysis can provide an insight into the structural aspects, which control performance during severe earthquakes. The analysis provides data on the strength and ductility of the structure, which cannot be obtained by elastic analysis. By pushover analysis, the base shear versus top displacement curve of the structure, usually called capacity curve, is obtained. To evaluate whether a structure is adequate to sustain a certain level of seismic loads, its capacity has to be compared with the requirements corresponding to a scenario event.

In pushover analyses, both the force distribution and target displacement are based on very restrictive assumptions, i.e. at time-independent displacement shape. Thus, it is in principle inaccurate for structures where higher mode effects are significant, and it may not detect the structural weaknesses that may be generated when the structures dynamic characteristics change after the formation of the first local plastic mechanism. One practical possibility to partly overcome the limitations imposed by pushover analysis is to assume two or three different displacements shapes (local patterns).

\section{ANALYTICAL MODELLING}

Model 1: Building has no walls in the first storey and one full brick infill masonry walls $(230 \mathrm{~mm}$ thick.) in the upper storeys. The building is modeled as bare frame. However masses of the walls are included.

Model 2: Building has no walls in the first storey and one full brick infill masonry walls (230 $\mathrm{mm}$ thick.) in the upper storeys. Stiffness and mass of the walls are considered.

Model 3: Building has one full brick infill masonry wall in the upper storeys. In ground storey, walls are provided in all the bays along periphery in longitudinal direction and in transverse direction, walls are provided at the end bays along periphery. The stiffness and mass of the walls are included.

The difference between symmetric and asymmetric considered models are, symmetric building models are having equal height of columns in ground storey where as in the case of asymmetric building models column height varies from $3 \mathrm{~m}$ to $5 \mathrm{~m}$ in ground. 


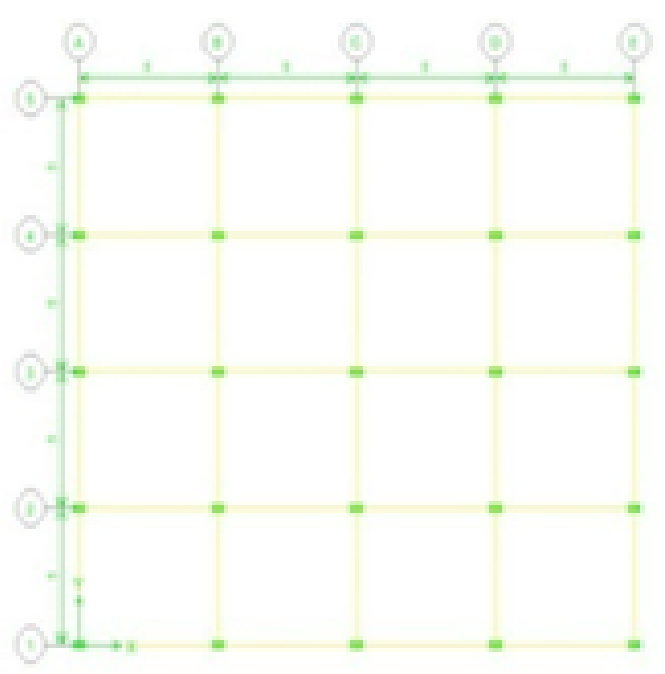

Fig 1: Plan Model-1

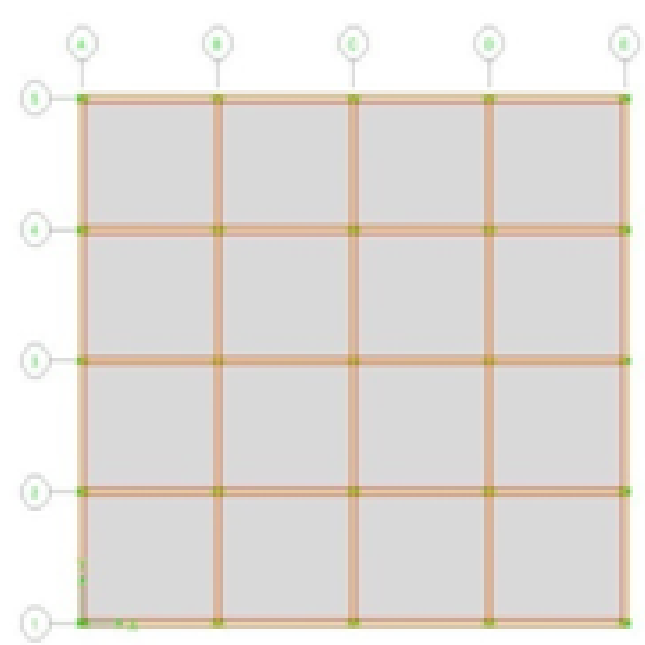

Fig 2: Plan Model-2

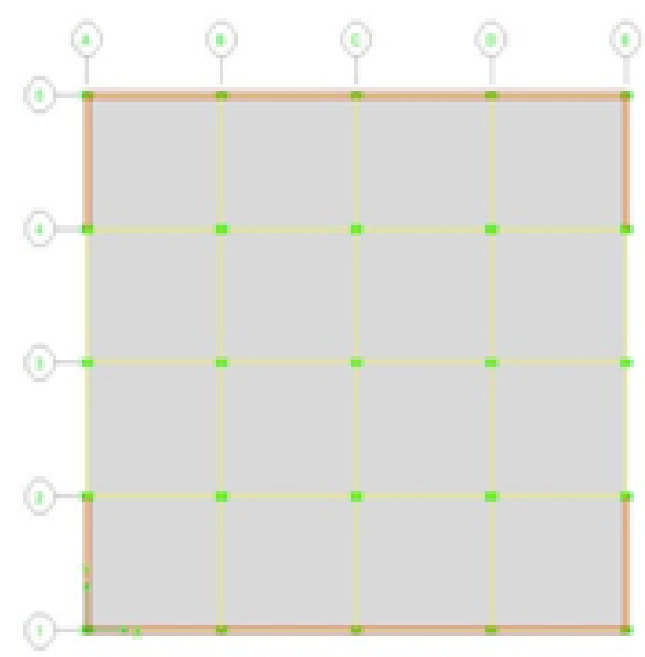

Fig 3: Plan Model-3:

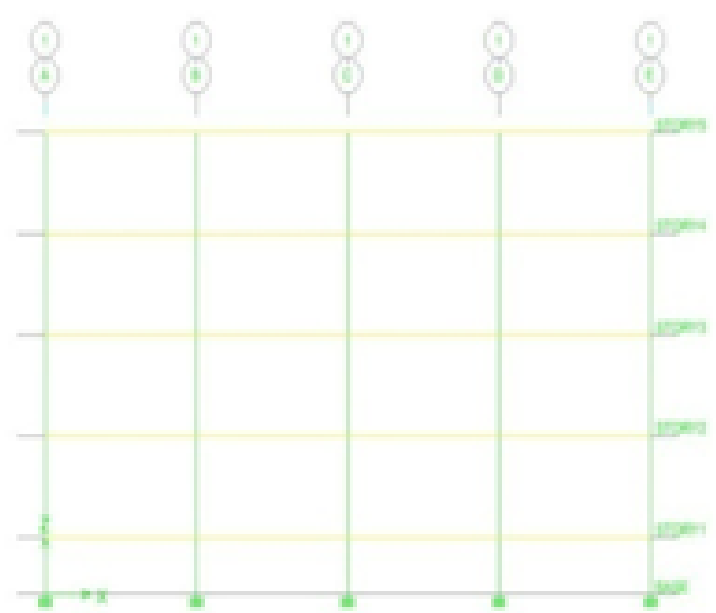

Fig 4: 3D View 4 Storeyed Model-1.

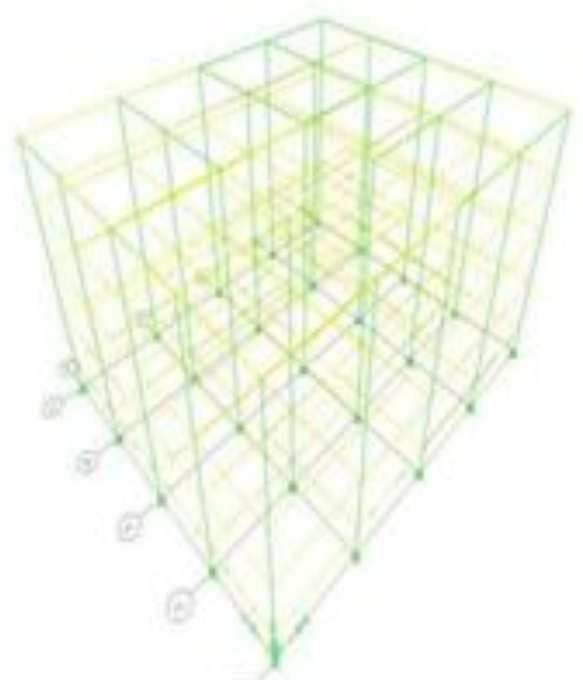

Fig 5: 3D View 4 Storeyed Model-1.

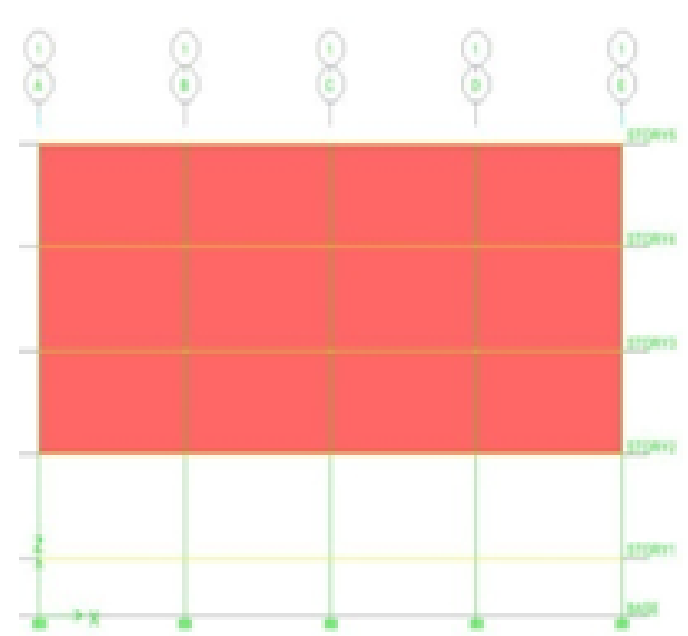

Fig 6: Elevation View 4 Storeyed Model-2 


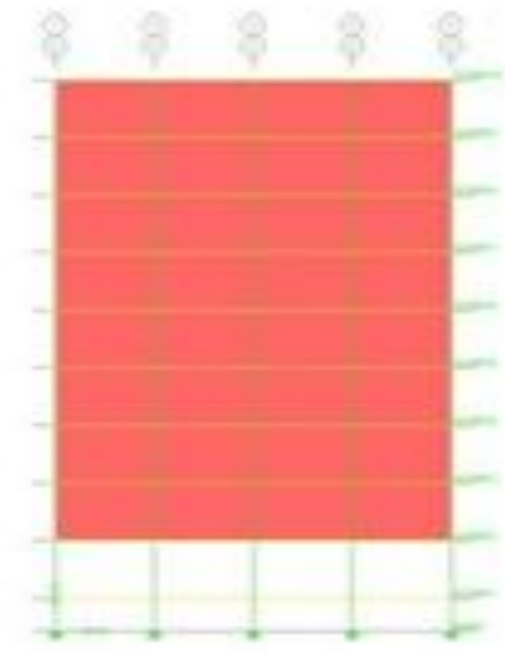

Fig 7: Elevation nine Storeyed Model-2.

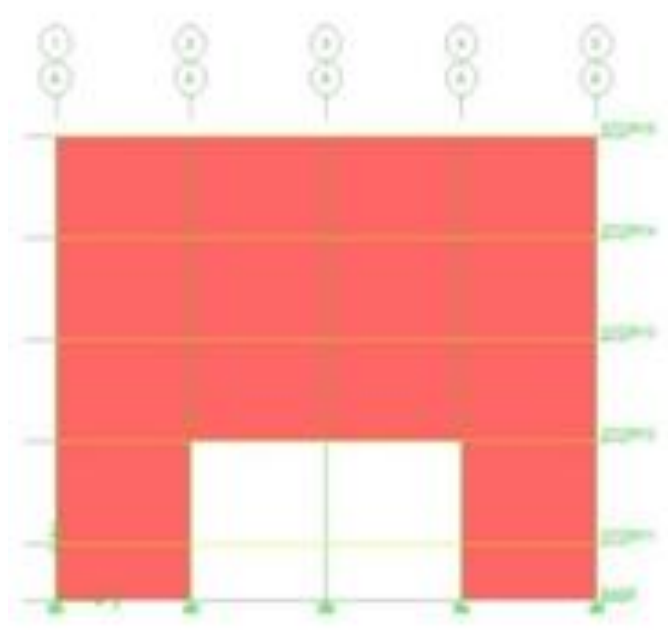

Fig 8: Elevation View 4 Storeyed Model-3.

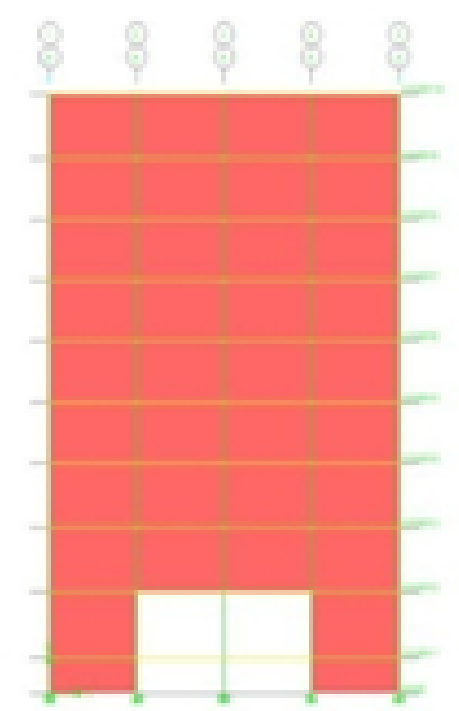

Fig 9: Elevation View 9 Storeyed Model-3.

\subsection{Pushover Analysis:}

ETABS is a general purpose finite element analysis program for static and dynamic analysis of two and threedimensional linear and nonlinear structures with a particular emphasis on dynamic loading and earthquake loading. The particular program used for this study, ETABS Nonlinear, is capable of performing pseudo-static nonlinear pushover analysis and nonlinear time - history analysis.

For pushover analysis, nonlinear behavior is assumed to occur within frame elements at concentrated plastic hinges with default or user-defined hinge properties being assigned to each hinge. The default hinge types include an uncoupled moment hinge and a coupled axial force and biaxial bending moment hinge. The latter is a hinge which yields based on the interaction of axial force and bending moments at the hinge location. In addition to the default and user-defined hinge properties, there are generated hinge properties. The default or user-defined hinge properties are assigned to frame elements and ETABS then creates, for each hinge, a different generated hinge property which is used in the pushover analysis. The generated hinge properties make use of the frame element section information and the default or used-defined hinge properties to fully define the plastic hinge properties. The main advantage of using default or user-defined hinge properties combined with generated hinge properties is that the process of defining a large number of hinge properties is simplified. The default hinges properties are section dependent and are typically based on the nonlinear modeling parameters given in Table 9-6 of the ATC - 40 documents.

Once the plastic hinge properties have been defined, the next step is to define the static pushover cases and the type of pushover analysis to be performed. In general, a pushover analysis consists of more than one pushover case. Typically, the analysis might consist of two load cases. The first load case would apply gravity load to the building and the second load case would apply a specific lateral load pattern to the building.

In ETABS, there are four different types of lateral load patterns to describe the distribution of loads on the structure for a pushover load case. The load patterns are:

1) Uniform acceleration (i.e. an equal acceleration imposed simultaneously on each lumped mass in the direction of one of the global axes)

2) A force that is proportional to the product of a specified mode shape multiplied by its circular frequency squared multiplied by the mass tributary to a node

3) An arbitrary static load pattern and

4) A combination of the above mentioned patterns.

Regarding the type of pushover analysis is, ETABS can perform either force-controlled analysis where the pushover proceeds to the full load value defined by the load pattern or displacement-controlled analysis where the pushover proceeds to the specified displacement in the specified direction at the specified node. In this study, the pushover 
curve was obtained using ETABS by first analyzing the building under the effect of dead load and then pushing the building longitudinally until either the prescribed maximum displacement (displacement - controlled analysis) was achieved at the control node or the building failed. At this point, the hinges are regarded as having reached their curvature capacity and the analysis is note that the condition of each plastic hinge is indicated by its colour as per a colour code that is provided on the bottom of the window. Furthermore, the use of color-codes to define hinge behavior allows the user to observe the evolution of damage in the structure.

Table1: Building Dimensions.

\begin{tabular}{|l|l|l|}
\hline Design variable & Value & Reference \\
\hline $\begin{array}{l}\text { Dead loads } \\
\text { (a)Masonry } \\
\text { (b) Concrete }\end{array}$ & $20 \mathrm{kN} / \mathrm{m}^{3}$ & IS \\
\hline $\begin{array}{l}\text { Live loads } \\
\text { (a) Floor load }\end{array}$ & $3 \mathrm{kN} / \mathrm{m}^{3}$ & $875: 1987$ (part 1) \\
$\begin{array}{l}\text { (b) Roof load } \\
\text { (c) Floor Finishes }\end{array}$ & $\begin{array}{l}2.0 \mathrm{kN} / \mathrm{m}^{2} \\
1.0 \mathrm{kN} / \mathrm{m}^{2}\end{array}$ & $875: 1987$ (part 2) \\
\hline Importance factor & 1.0 & IS 1893:2002 \\
\hline $\begin{array}{l}\text { Response } \\
\text { Reduction Factor }\end{array}$ & 5 & IS 1893:2002 \\
\hline
\end{tabular}

The results from pushover analysis can be displayed in a variety of formats including the pushover-deformed shape, the sequence of pushover hinge formation, frame element forces at each step of the pushover, and the capacity curve (i.e., the pushover curve converted to ADRS format). The pushover curve is converted by ETABS to ADRS format based on Equations (8-1) through (8-4) in the ATC-40 document.

Table2: Building Dimensions.

\begin{tabular}{|l|l|}
\hline Slab thickness & $120 \mathrm{~mm}$ \\
\hline Beam dimensions & $250 \mathrm{~mm}$ x 600 mm \\
\hline & $250 \mathrm{~mm} \times 500 \mathrm{~mm}$ (4 Storey: \\
& All Storeys) \\
& $350 \mathrm{~mm} \times 700 \mathrm{~mm}$ (9 Storey: \\
Column dimensions & 1 to 6 Storeys) \\
& $250 \mathrm{~mm} \times 500 \mathrm{~mm}$ (9 Storey: \\
& 6 to 10 Storeys) \\
\hline Infills $\quad$ Wall & $250 \mathrm{~mm}$ \\
\hline
\end{tabular}

\begin{tabular}{|l|l|}
\hline Thickness & \\
\hline $\begin{array}{l}\text { Grade of Concete } \\
\text { and Steel }\end{array}$ & M25 concrete, Fe 415 steel \\
\hline
\end{tabular}

\section{RESULTS.}

\subsection{Natural Periods}

Analytical Periods differ from the Codal periods.

Table 3: Codal and Analytical Periods.

\begin{tabular}{|c|c|c|c|}
\hline \multirow{3}{*}{ Model } & \multicolumn{3}{|c|}{ Natural Periods (sec) } \\
\hline & \multirow{2}{*}{ Codal } & \multicolumn{2}{|l|}{ Analysis } \\
\hline & & \begin{tabular}{|l|} 
Sym. \\
Building
\end{tabular} & \begin{tabular}{|l} 
Asym. \\
Building
\end{tabular} \\
\hline \multicolumn{4}{|c|}{ Four Storeyed Building } \\
\hline 1 & 0.56 & 0.8044 & 0.6739 \\
\hline 2 & 0.26 & 0.5221 & 0.3413 \\
\hline 3 & 0.26 & 0.2691 & 0.2115 \\
\hline \multicolumn{4}{|c|}{ Nine Storeyed Building } \\
\hline 1 & 0.98 & 1.5900 & 1.5111 \\
\hline 2 & 0.56 & 0.6394 & 0.5100 \\
\hline 3 & 0.56 & 0.4265 & 0.3909 \\
\hline
\end{tabular}

3.2 Base Shear $(\mathrm{KN})$ and Displacement $(\mathrm{mm})$ at Yield Point:

Table 4: Base Shear and displacements along longitudinal direction

\begin{tabular}{|l|l|l|l|}
\hline \multirow{2}{*}{ Description } & Model & $\begin{array}{l}\text { Four storeyed building } \\
\text { models }\end{array}$ \\
\cline { 2 - 4 } & $\begin{array}{l}\text { Base } \\
\text { shear at at } \\
\text { first hinge }\end{array}$ & $\begin{array}{l}\text { Displacement } \\
\text { at first hinge }\end{array}$ \\
\hline \multirow{2}{*}{$\begin{array}{l}\text { Symmetric } \\
\text { models }\end{array}$} & 1 & 462.68 & 5.86 \\
\cline { 2 - 4 } & 2 & 4433.2 & 5.78 \\
\cline { 2 - 4 } $\begin{array}{l}\text { Asymmetric } \\
\text { models }\end{array}$ & 3 & 4750.59 & 4.95 \\
\cline { 2 - 4 } & 2 & 460.69 & 4.91 \\
\cline { 2 - 4 } & 3 & 6434.0 & 3.08 \\
\hline
\end{tabular}

Table 5: Base Shear and displacements along longitudinal direction

\begin{tabular}{|l|l|l|l|}
\hline \multirow{3}{*}{ Description } & \multirow{2}{*}{ Model } & \multicolumn{2}{|l|}{ Nine storeyed building models } \\
\cline { 3 - 4 } & $\begin{array}{l}\text { Base shear at } \\
\text { first hinge }\end{array}$ & $\begin{array}{l}\text { Base shear at } \\
\text { first hinge }\end{array}$ \\
\hline \multirow{3}{*}{ Symmetric models } & 1 & 766.92 & 16.85 \\
\hline & 2 & 2021.98 & 5.34 \\
\hline & 3 & 6819.1 & 10.20 \\
\hline \multirow{3}{*}{ Asymmetric models } & 1 & 647.9 & 12.79 \\
\cline { 2 - 4 } & 2 & 2183.11 & 2.71 \\
\cline { 2 - 4 } & 3 & 10361.10 & 14.48 \\
\hline
\end{tabular}


Table 6: Base Shear and displacements along transverse direction

\begin{tabular}{|c|c|c|c|c|c|}
\hline \multirow[b]{2}{*}{ Description } & \multirow[b]{2}{*}{ Model } & \multicolumn{2}{|l|}{ Four storeyed } & \multicolumn{2}{|c|}{ Nine storeyed building models } \\
\hline & & $\begin{array}{l}\text { Base shear at first } \\
\text { hinge }\end{array}$ & $\begin{array}{l}\text { Displacement at first } \\
\text { hinge }\end{array}$ & $\begin{array}{l}\text { Base shear at first } \\
\text { hinge }\end{array}$ & $\begin{array}{l}\text { Displacement at first } \\
\text { hinge }\end{array}$ \\
\hline \multirow{3}{*}{$\begin{array}{l}\text { Symmetric } \\
\text { models }\end{array}$} & 1 & 876.4 & 24.82 & \begin{tabular}{|l|l|}
649.74 \\
\end{tabular} & 23.67 \\
\hline & 2 & 1191.9 & 14.60 & 1511.58 & 8.11 \\
\hline & 3 & 2417.0 & 6.70 & 2704.37 & 6.77 \\
\hline \multirow{3}{*}{$\begin{array}{l}\text { Asymmetric } \\
\text { models }\end{array}$} & 1 & 617.41 & 18.98 & 599.54 & 23.66 \\
\hline & 2 & 608.11 & 7.30 & 633.25 & 3.38 \\
\hline & 3 & 1928.0 & 4.38 & 1474.70 & 3.38 \\
\hline
\end{tabular}

\subsection{For Four Storeyed Building Models:}

Table 7: Lateral displacements ( $\mathrm{mm}$ ) along longitudinal and transverse directions for model-1

\begin{tabular}{|l|l|l|l|l|l|l|l|l|}
\hline \multirow{3}{*}{ Storey No. } & \multicolumn{4}{l}{ Symmetric Building } & \multicolumn{2}{l|}{ Asymmetric Building } \\
\cline { 2 - 9 } & $\begin{array}{l}\text { Response spectrum } \\
\text { method }\end{array}$ & Pushover Analysis & \multicolumn{2}{l|}{ Response spectrum method } & \multicolumn{2}{l|}{ Pushover Analysis } \\
\cline { 2 - 9 } & Ux & Uy & Ux & Uy & Ux & Uy & Ux & Uy \\
\hline 4 & 5.92 & 8.73 & 5.9 & 19.37 & 5.056 & 9.185 & 4.917 & 18.98 \\
\hline 3 & 5.37 & 7.95 & 5.44 & 18.00 & 4.371 & 8.331 & 4.239 & 17.267 \\
\hline 2 & 4.13 & 6.17 & 4.35 & 14.55 & 3.016 & 6.492 & 2.929 & 13.439 \\
\hline 1 & 2.27 & 3.74 & 2.81 & 9.00 & 1.240 & 3.788 & 1.233 & 7.771 \\
\hline
\end{tabular}

Table 8: Lateral displacements ( $\mathrm{mm}$ ) along longitudinal and transverse directions for model-2

\begin{tabular}{|l|l|l|l|l|l|l|l|l|}
\hline \multirow{3}{*}{ Storey No. } & \multicolumn{9}{l}{ Symmetric Building } & \multicolumn{2}{l|}{ Asymmetric Building } \\
\cline { 2 - 9 } & $\begin{array}{l}\text { Response } \\
\text { method }\end{array}$ & \multicolumn{2}{|l|}{ spectrum } & \multicolumn{2}{l|}{ Pushover Analysis } & \multicolumn{2}{l|}{ Response spectrum method } & \multicolumn{2}{l|}{ Pushover Analysis } \\
\cline { 2 - 9 } & Ux & Uy & Ux & Uy & Ux & Uy & Ux & Uy \\
\hline 4 & 3.38 & 5.42 & 5.83 & 13.557 & 1.30 & 3.01 & 1.99 & 7.3 \\
\hline 3 & 3.35 & 5.39 & 5.701 & 13.507 & 1.36 & 2.99 & 2.00 & 7.258 \\
\hline 2 & 3.30 & 5.35 & 5.683 & 13.455 & 1.31 & 2.95 & 2.00 & 7.192 \\
\hline 1 & 3.24 & 5.20 & 5.411 & 13.394 & 1.22 & 2.89 & 1.94 & 7.08 \\
\hline
\end{tabular}

Table9: Lateral displacements ( $\mathrm{mm}$ ) along longitudinal and transverse directions for model-3

\begin{tabular}{|l|l|l|l|l|l|l|l|l|}
\hline \multirow{3}{*}{ Storey No. } & \multicolumn{9}{l|}{ Symmetric Building } \\
\cline { 2 - 9 } & $\begin{array}{l}\text { Response } \\
\text { method }\end{array}$ & \multicolumn{2}{|l|}{ spectrum } & \multicolumn{2}{l|}{ Pushover Analysis } & \multicolumn{2}{l|}{ Response spectrum method } & Pushover Analysis \\
\cline { 2 - 9 } & Ux & Uy & Ux & Uy & Ux & Uy & Ux & Uy \\
\hline 4 & 0.42 & 0.88 & 4.805 & 11.72 & 0.485 & 1.193 & 3.085 & 1.925 \\
\hline 3 & 0.39 & 0.84 & 4.612 & 11.24 & 0.453 & 1.157 & 2.924 & 1.904 \\
\hline 2 & 0.34 & 0.77 & 4.313 & 10.45 & 0.397 & 1.098 & 2.601 & 1.901 \\
\hline 1 & 0.26 & 0.67 & 3.991 & 9.33 & 0.320 & 1.015 & 2.13 & 1.85 \\
\hline
\end{tabular}

\subsection{For Nine Storeyed Building Models:}

Table10: Lateral displacements (mm) along longitudinal and transverse directions for model-1.

\begin{tabular}{|c|c|c|c|c|c|c|c|c|}
\hline \multirow{3}{*}{ Storey No. } & \multicolumn{4}{|c|}{ Symmetric Building } & \multicolumn{4}{|c|}{ Asymmetric Building } \\
\hline & \multicolumn{2}{|c|}{$\begin{array}{|ll|}\begin{array}{l}\text { Response } \\
\text { method }\end{array} & \text { spectrum } \\
\end{array}$} & \multicolumn{2}{|c|}{ Pushover Analysis } & \multicolumn{2}{|c|}{$\begin{array}{|ll|}\begin{array}{l}\text { Response spectrum } \\
\text { method }\end{array} & \\
\end{array}$} & \multicolumn{2}{|c|}{ Pushover Analysis } \\
\hline & $\mathrm{Ux}$ & Uy & Ux & Uy & Ux & Uy & Ux & Uy \\
\hline 9 & 12.947 & 14.83 & 16.394 & 38.600 & 10.97 & 13.14 & 12.417 & 22.771 \\
\hline 8 & 12.233 & 13.52 & 15.395 & 36.990 & 10.19 & 11.88 & 11.613 & 20.884 \\
\hline 7 & 11.203 & 11.69 & 13.911 & 34.508 & 9.08 & 10.11 & 10.368 & 18.031 \\
\hline 6 & 9.903 & 9.46 & 11.941 & 31.136 & 7.70 & 7.99 & 8.722 & 14.358 \\
\hline
\end{tabular}




\begin{tabular}{|l|l|l|l|l|l|l|l|l|}
\hline 5 & 8.381 & 8.33 & 10.332 & 26.887 & 6.56 & 6.93 & 7.372 & 12.455 \\
\hline 4 & 6.623 & 7.04 & 8.497 & 21.766 & 5.29 & 5.71 & 5.858 & 10.33 \\
\hline 3 & 4.642 & 5.60 & 6.489 & 15.781 & 3.86 & 4.34 & 4.208 & 7.999 \\
\hline 2 & 2.491 & 3.99 & 4.357 & 8.940 & 2.34 & 2.82 & 2.498 & 5.511 \\
\hline 1 & 1.212 & 2.25 & 2.232 & 5.530 & 0.89 & 1.27 & 0.92 & 2.882 \\
\hline
\end{tabular}

Table11: Lateral displacements ( $\mathrm{mm}$ ) along longitudinal and transverse directions for model-2.

\begin{tabular}{|c|c|c|c|c|c|c|c|c|}
\hline \multirow{3}{*}{ Storey No. } & \multicolumn{4}{|c|}{ Symmetric Building } & \multicolumn{4}{|c|}{ Asymmetric Building } \\
\hline & \multicolumn{2}{|c|}{$\begin{array}{l}\text { Response } \\
\text { method }\end{array}$} & \multicolumn{2}{|c|}{ Pushover Analysis } & \multicolumn{2}{|c|}{ Response spectrum method } & \multicolumn{2}{|c|}{ Pushover Analysis } \\
\hline & Ux & Uy & Ux & Uy & Ux & Uy & Ux & Uy \\
\hline 9 & 5.430 & 8.732 & 7.748 & 14.203 & 3.10 & 6.18 & 2.693 & 3.32 \\
\hline 8 & 5.356 & 8.669 & 7.644 & 14.103 & 2.96 & 6.05 & 2.641 & 3.249 \\
\hline 7 & 5.280 & 8.604 & 7.538 & 13.999 & 2.79 & 5.89 & 2.558 & 3.166 \\
\hline 6 & 5.124 & 8.540 & 7.431 & 13.895 & 2.60 & 5.72 & 2.445 & 3.074 \\
\hline 5 & 5.045 & 8.473 & 7.300 & 13.682 & 2.40 & 5.53 & 2.314 & 2.974 \\
\hline 4 & 4.966 & 8.407 & 7.209 & 13.525 & 2.17 & 5.33 & 2.162 & 2.866 \\
\hline 3 & 4.882 & 8.340 & 7.098 & 13.464 & 1.93 & 5.12 & 1.994 & 2.751 \\
\hline 2 & 4.800 & 8.272 & 6.981 & 13.451 & 1.70 & 4.90 & 1.827 & 2.635 \\
\hline 1 & 4.790 & 8.219 & 6.901 & 12.201 & 1.40 & 4.63 & 1.587 & 2.49 \\
\hline
\end{tabular}

Table 12: Lateral displacements (mm) along longitudinal and transverse directions for model-3.

\begin{tabular}{|c|c|c|c|c|c|c|c|c|}
\hline \multirow{3}{*}{$\begin{array}{l}\text { Storey } \\
\text { No. }\end{array}$} & \multicolumn{4}{|c|}{ Symmetric Building } & \multicolumn{4}{|c|}{ Asymmetric Building } \\
\hline & \multicolumn{2}{|c|}{$\begin{array}{|ll|}\begin{array}{l}\text { Response } \\
\text { method }\end{array} & \text { spectrum } \\
\end{array}$} & \multicolumn{2}{|c|}{$\begin{array}{l}\text { Pushover } \\
\text { Analysis } \\
\end{array}$} & \multicolumn{2}{|c|}{$\begin{array}{|ll|}\begin{array}{l}\text { Response spectrum } \\
\text { method }\end{array} & \\
\end{array}$} & \multicolumn{2}{|c|}{$\begin{array}{l}\text { Pushover } \\
\text { Analysis }\end{array}$} \\
\hline & $\mathrm{Ux}$ & Uy & Ux & Uy & $\mathrm{Ux}$ & Uy & Ux & Uy \\
\hline 9 & 1.90 & 3.125 & 9.663 & 6.479 & 2.08 & 3.96 & 13.704 & 3.241 \\
\hline 8 & 1.75 & 2.95 & 9.068 & 6.156 & 1.94 & 3.75 & 12.747 & 3.075 \\
\hline 7 & 1.59 & 2.753 & 8.372 & 5.792 & 1.77 & 3.52 & 11.624 & 2.884 \\
\hline 6 & 1.4 & 2.537 & 7.593 & 5.397 & 1.58 & 3.26 & 10.352 & 2.67 \\
\hline 5 & 1.2 & 2.306 & 6.747 & 4.975 & 1.37 & 2.98 & 8.993 & 2.44 \\
\hline 4 & 1.02 & 2.067 & 5.84 & 4.524 & 1.16 & 2.68 & 7.541 & 2.196 \\
\hline 3 & 0.81 & 1.950 & 4.89 & 4.054 & 0.93 & 2.37 & 6.033 & 1.943 \\
\hline 2 & 0.58 & 1.549 & 3.91 & 3.566 & 0.70 & 2.06 & 4.518 & 1.687 \\
\hline 1 & 0.26 & 1.549 & 2.853 & 2.953 & 0.47 & 1.74 & 2.979 & 1.425 \\
\hline
\end{tabular}

\section{CONCLUSION}

1) Fundamental natural period decreases when effect of infill wall is considered.

2) Storey drifts are found within the limit as specified by code (IS: 1893-2002, part-1) in both linear dynamic and nonlinear static analysis.

3) Base shear and displacement at first hinge are less in asymmetric building models compared to symmetric building models.

4) The presence of masonry infill influences the overall behavior of structures when subjected to lateral forces.

5) Joint displacements and storey drifts are considerably reduced while contribution of the infill brick wall is taken into account.

\section{REFERENCES}

[1] Agarwal.P. and Shrikhande. M., 2006 "Earthquake Resistant Design of Structures" Prentice-Hall of India Private Limited, New Delhi, India.

[2] Arlekar N.J., Jain K.S., and Murthy C.V.R, "Seismic Response of RC Frame Buildings with Soft First Storeys" Proceedings of the CBRL Golden Jubilee Conference on Natural Hazards in Urban Habitat, New Delhi, 1997.

[3] Applied Technology Council (1996): "Seismic Evaluation and Retrofit of Concrete Buildings", ATC-40, Volume 1.

[4] Brick infills in RC frames: "E-Conference Proceeding", January 28, 2002. 
[5] IS: 1983 (Part-I) - 2002 "Criteria for Earthquake Resistant Design of Structures", Part 1 - General provisions and buildings, fifth revision, Bureau of Indian Standards, New Delhi.

[6] Krawinkler H. and Seneviratna G.D.P.K (1998): "Pros and Cons of Pushover Analysis of Seismic Performance Evaluation".

[7] Kanitkar R. and Kanitkar V., "Seismic Performance of Conventional Multi-storey Buildings with open ground storey for Vehicular Parking", Indian Concrete Journal, February 2004.

[8] Lee H.S. and Woo W.S., "Effect of Masonry infills on Seismic Performance of a 3 Storey RC Frame with non-seismic Detailing", John Wiley \& Sons, Ltd., 2001.

[9] Murthy C.V.R. and Jain S.K., "The Beneficial Influence of Masonry Infill Walls on the Seismic Performance of RC Framed Buildings", Indian Institute of Technology, Kanpur, $12^{\text {th }}$ World Conference on Earthquake Engineering, January 2000, Auckland, New Zealand.

[10] Naik. Pramodini, Dyavanal S.S., and Annigeri. S.A., "Performance Evaluation of Multistoreyed Buildings Subjected to Earthquake Forces", Proceedings of National Conference on Earthquake Analysis and Design of Structures 2006, A-93 - A101.

[11] Ravi Sinha et al: "Earthquake Resistant Capacity of Reinforced Concrete Frame Buildings", Technical Project Report Volume 2, Indian Institute of Technology, Bombay.

[12] Gupta B, Kunnath SK. “Adaptive spectra-based pushover procedure for seismic evaluation of structures.” Earthquake Spectra, 2000, 16(2):367392.

[13] ATC-40. "Seismic evaluation and retrofit of concrete buildings." Volume 1 and 2. Applied Technology Council, California, 1996.

[14] FEMA-273. "NEHRP guidelines for the seismic rehabilitation of buildings." Federal Emergency Management Agency, Washington DC, 1997.

[15] ETABS nonlinear version 9.7.0. Computers and Structures, Inc, CA.

[16] Naeim F (Ed). "The seismic design handbook." Chapter 15. Kluwer Academic Publishers, MA, 2001 . 